J Venom Anim Toxins incl Trop Dis, 2019 25: e147418

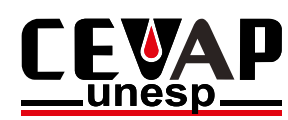

The Journal of Venomous Animals and

Toxins including Tropical Diseases

ISSN 1678-9199

Journal homepage www.jvat.org

\title{
Identification of a pore-forming protein from sea anemone Anthopleura dowii Verrill (1869) venom by mass spectrometry
}

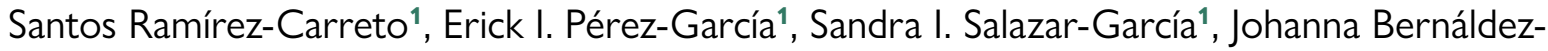 \\ Sarabia² ${ }^{2}$ Alexei Licea-Navarro², Enrique Rudiño-Piñera ${ }^{1}$, Leonor Pérez-Martínez', Gustavo \\ Pedraza-Alva ${ }^{1}$, Claudia Rodríguez-Almazán ${ }^{1, *}$ \\ 1 Universidad Nacional Autónoma de México, Instituto de Biotecnología, Departamento de Medicina Molecular y Bioprocesos, Av. Universidad 2001, \\ Cuernavaca, Morelos, México. \\ ${ }^{2}$ Centro de Investigación Científica y de Educación Superior de Ensenada, Departamento de Innovación Biomédica, Baja California, \\ México.
}

\section{Article Info \\ Keywords:}

Anthopleura

pore-forming protein

Venom

lung carcinom

sea anemone.

\begin{abstract}
Background: Pore-forming proteins (PFP) are a class of toxins abundant in the venom of sea anemones. Owing to their ability to recognize and permeabilize cell membranes, pore-forming proteins have medical potential in cancer therapy or as biosensors. In the present study, we showed the partial purification and sequencing of a pore-forming protein from Anthopleura dowii Verrill (1869).

Methods: Cytolytic activity of $A$. dowii Verrill (1869) venom was determined via hemolysis assay in the erythrocytes of four mammals (sheep, goat, human and rabbit). The cytotoxic activity was analyzed in the human adherent lung carcinoma epithelial cells (A549) by the cytosolic lactate dehydrogenase (LDH) assay, and trypan blue staining. The venom was fractionated via ammonium sulfate precipitation gradient, dialysis, and ion exchange chromatography. The presence of a pore-forming protein in purified fractions was evaluated through hemolytic and cytotoxic assays, and the activity fraction was analyzed using the percent of osmotic protections after polyethylene glycol (PEG) treatment and mass spectrometry.

Results: The amount of protein at which the venom produced $50 \%$ hemolysis $\left(\mathrm{HU}_{50}\right)$ was determined in hemolysis assays using erythrocytes from sheep $\left(\mathrm{HU}_{50}=10.7 \pm 0.2\right.$ $\mu \mathrm{g})$, goat $\left(\mathrm{HU}_{50}=13.2 \pm 0.3 \mu \mathrm{g}\right)$, rabbit $\left(\mathrm{HU}_{50}=34.7 \pm 0.5 \mu \mathrm{g}\right)$, and human $\left(\mathrm{HU}_{50}=25.6\right.$ $\pm 0.6 \mu \mathrm{g})$. The venom presented a cytotoxic effect in A549 cells and the protein amount present in the venom responsible for producing $50 \%$ death $\left(\mathrm{IC}_{50}\right)$ was determined using a trypan blue cytotoxicity assay $(1.84 \pm 0.40 \mu \mathrm{g} / \mathrm{mL})$. The loss of membrane integrity in the A549 cells caused by the venom was detected by the release of LDH in proportion to the amount of protein. The venom was fractionated; and the fraction with hemolytic
\end{abstract}

\footnotetext{
* Correspondence:

claudiar@comunidad.unam.mx

https://dx.doi.org/10.1590/1678-9199-JVATITD-1474-18

Received: 10 July 2018; Accepted: 13 November 2018; Published online: 11 February 2019
}

On-line ISSN 1678-9199 (c) The Author(s). 2019 Open Access This article is distributed under the terms of the Creative Commons Attribution 4.0 International License (http:// creativecommons org/licenses/by/4.0/), which permits unrestricted use, distribution, and reproduction in any medium, provided you give appropriate credit to the original author(s) and the source, provide a link to the Creative Commons license, and indicate if changes were made. The Creative Commons Public Domain Dedication waiver (http://creativecommons.org/ publicdomain/zero/1.0/) applies to the data made available in this article, unless otherwise stated. 
and cytotoxic activities was analyzed by mass spectrometry. A pore-forming protein was identified. The cytotoxicity in the A549 cells produced by the fraction containing the pore-forming protein was osmotically protected by PEG-3350 Da molecular mass, which corroborated that the loss of integrity in the plasma membrane was produced via pore formation.

Conclusion: A. dowii Verrill (1869) venom contains a pore-forming protein suitable for designing new drugs for cancer therapy.

\section{Background}

Research on compounds derived from marine organisms has increased over the last four decades, and has focused on elucidating the mechanism of action of these compounds mainly to be applied in biomedicine [1]. The phylum Cnidaria is an ancient group with four main classes including corals, jellyfish, hydrozoans, and sea anemone $[2,3]$. The principal characteristic of this group is the production of nematocysts that are distributed in different tissues [4]. Nematocysts contain toxic compounds that are used against predators to protect their territory and to capture their prey [5].

The venom of cnidarians is composed of polypeptides such as cytolysins, protease inhibitors, proteases, neurotoxins, and phospholipases, and non-protein molecules such as serotonin and histamine $[6,7]$. The components of the venom have been determined by different strategies, e.g., electrical stimulation of the organism [8], isolation of nematocysts from the tentacles $[9,10]$, and homogenization of the entire organism (extract) [11]. As a first step, to explore any potential applicability, the presence of toxins in the venom is identified by different bioassays $[12,13]$ and the molecules with a potential specific function are purified $[10,14]$. Additionally, toxins immersed in the nematocyte matrix have been proven to target the plasma membrane $[15,16]$. Several sea anemone toxins have been studied for the development of drugs to serve as therapeutic agents with antitumor activity, as well as vasodilators, and ion channel modulators [17-22].

Among the different proteins identified from sea anemones are molecules capable of producing cytolysis. Cytolysins are classified into four groups based on their molecular weight and function as follows: 5 - $8 \mathrm{kDa}$ antihistamine peptides, $\sim 20 \mathrm{kDa}$ pore-forming proteins or actinoporins, $30-40 \mathrm{kDa}$ cytolysins with or without phospholipase $\mathrm{A}_{2}$ activity, and 80 $\mathrm{kDa}$ cytolysin isolated from Metridium senile with activity inhibited by cholesterol [23]. Actinoporins are the most studied cytolysin in sea anemones to date. These toxins form monomers in solution that binds to the membrane of a target cell, leading to pore formation [24-26]. Recently, the presence of a pre-pore was demonstrated as an intermediary in the action mechanism of actinoporins [27,28]. The pores produced by actinoporins alter the integrity of the membrane, producing an ionic imbalance that can lead to cell death $[29,30]$. The binding of actinoporins to the plasma membrane is determined by selective binding to sphingomyelin. This property is relevant to their use in cancer therapy $[28,29]$ because it has been demonstrated that the lipids of the membranes of tumor cells present a significantly altered composition, particularly with a higher concentration of sphingomyelin [31,32]. The N-terminal region of actinoporins has an important role in the specificity of these proteins and can be internalized in the plasmatic membrane $[33,34]$. Several research groups have designed immunotoxins from the N-terminal of actinoporins $[18,35]$, these conjugates can alter the cell membrane by producing cytotoxicity in tumor cells [36].

Lung cancer is one of the main causes of mortality worldwide $[37,38]$. Therefore, it is important to search for new compounds that have antitumor potential. In the present study, we analyzed the cytolytic and cytotoxic activities of venom from the sea anemone A. dowii Verrill (1869). We determined the amount of protein at which $50 \%$ of the erythrocytes were lysed $\left(\mathrm{HU}_{50}\right)$ and at which $50 \%$ of A549 cells died. The hemolytic activity was assayed in erythrocytes from four mammals (sheep, goat, rabbit and human). The morphological changes of the A549 cells produced by the venom were observed by light microscopy. We suggest that the cytolytic effect was due to a pore-forming protein in the venom after analyzing the osmotic protectant effect of polyethylene glycol (PEG) and mass spectrometry. The cytotoxic activity was assayed in the A549 cell line (adenocarcinomic human alveolar basal epithelial cells), and was determined via trypan-blue-dye uptake and the lactate-dehydrogenase (LDH) release.

\section{Methods \\ Specimen collection}

Four specimens of $A$. dowii Verrill (1869) were collected from the intertidal zone in Ensenada, Baja California, México. This species of sea anemone has been identified previously [39]. The organisms were transported to the laboratory where they were frozen and lyophilized, and then the samples were stored at $-20^{\circ} \mathrm{C}$ until subsequent use.

\section{Venom extraction}

Forty milligrams of the lyophilized organisms was rehydrated with $125 \mathrm{~mL}$ of $50 \mathrm{mM}$ sodium phosphate, $\mathrm{pH}$ 7.4, with protease inhibitor (Complement Protease Inhibitor Cocktail, Roche), after dissolving a protease inhibitor tablet in $1.5 \mathrm{~mL}$ of Milli Q water. The sample was mixed for $12 \mathrm{~h}$ at $4^{\circ} \mathrm{C}$, using a magnetic stirrer to increase nematocyst discharge and release of toxins. The extract was subjected to three cycles of freezing and thawing at $-20^{\circ} \mathrm{C}$ 
[40]. The resulting solution was centrifuged at $25,400 \mathrm{x} g$ for 40 min to remove cell debris. The supernatant was maintained at $-20^{\circ} \mathrm{C}$ until use. Before use, the venom was centrifuged at 8,000 $\mathrm{x} g$ and filtered through membranes with a $0.22 \mu \mathrm{m}$ pore size. The total protein concentration of the venom was determined via the Bradford assay [41]. The electrophoretic profile was examined by Tricine-SDS-PAGE on $15 \%$ polyacrylamide gels [42]. The gels were dyed with Coomasie blue.

\section{Hemolytic activity assay}

The hemolytic activity of the venom was detected by the hemoglobin of erythrocytes released in response to different venom protein concentrations. Two milliliters of peripheral blood of each organism (human, rabbit, sheep, and goat) was collected and mixed with anticoagulant solution. The human, sheep, rabbit, and goat erythrocytes were washed three times with Alsever solution ( $0.1 \mathrm{M}$ dextrose, $0.07 \mathrm{M} \mathrm{NaCl}, 0.002 \mathrm{M}$ citric acid, and $0.027 \mathrm{M}$ Sodium citrate, $\mathrm{pH}$ 7.4). The assay was performed in 96-well microtiter plates, with each well containing $20 \mu \mathrm{L}$ of erythrocyte solution $\left(1-2 \times 10^{6}\right.$ cells $\left./ \mathrm{mL}\right)$, a different protein concentration, and for the anticoagulant solution an appropriate volume was added to adjust each well to $200 \mu \mathrm{L}$. The samples were incubated at $37^{\circ} \mathrm{C}$ for $60 \mathrm{~min}$ and subsequently centrifuged at $804 \mathrm{xg}$ for $5 \mathrm{~min}$ at $4^{\circ} \mathrm{C}$. The amount of hemoglobin was spectrophotometrically monitored at $\lambda=$ $415 \mathrm{~nm}$ and the hemolysis percentage was calculated using the following equation:

$\%$ Hemolysis $=\left(A_{V}-A_{\text {buffer }}\right) /\left(A_{\text {water }}-A_{\text {buffer }}\right) \times 100$

where $A_{v}, A_{\text {buffer }}$, and $A_{\text {water }}$ are the absorbances $(A)$ of the supernatants of venom (V), buffer ( $0 \%$ hemolysis), and water (100\% hemolysis), respectively [43]. All hemolysis assays were performed in triplicate. The $\mathrm{HU}_{50}$ thus calculated represents the protein concentration from venom that produced $50 \%$ hemolysis.

\section{Human cell culture}

The human adherent lung carcinoma epithelial cells A549 were obtained from the American Type Culture Collection, USA. The cells were maintained in Gibco ${ }^{\mathrm{TM}}$ Dulbecco' s Modified Eagle Medium: Nutrient Mixture F-12 (DMEM-F12), supplemented with $5 \%$ fetal bovine serum, $2 \mathrm{mM}$ L-glutamine, $50 \mathrm{U} / \mathrm{mL}$ penicillin, and $50 \mathrm{mg} / \mathrm{mL}$ streptomycin. In all experiments that included the A549 cell line, the cells were seeded in 24well plates at $4 \times 10^{4}$ cells $/ \mathrm{mL}$ and were maintained at $37^{\circ} \mathrm{C}$ in $5 \% \mathrm{CO}_{2}$ for $48 \mathrm{~h}$. After this, an average of $2 \times 10^{5}$ cells per well were exposed to the venom and then incubated for $6 \mathrm{~h}$ at $37^{\circ} \mathrm{C}$ and $5 \% \mathrm{CO}_{2}$.

\section{Cell viability assay}

Cell viability assay was determined by trypan blue staining [44]. The cells were treated with trypsin, washed with $1 \mathrm{X}$ phosphate buffer saline (PBS), and resuspended in $1 \mathrm{~mL}$ of $1 \mathrm{X}$ PBS. Finally, cells were stained with trypan blue dye, with unstained cells counted as viable cells. The amount of protein present in the venom responsible for producing 50\% death $\left(\mathrm{IC}_{50}\right)$ in A549 cells was calculated through an adjusted mathematical model based on Boltzmann's sigmoidal equation. The morphological changes in the cells were observed by light microscopy (110x magnification) after $6 \mathrm{~h}$ of exposure to the venom.

\section{Cytotoxicity assay}

The cytotoxic activity of venom in the A549 cells was monitored by cytosolic LDH release [45]. Controls were considered the supernatants of cultured cells without venom (0\%) and cells were treated with $1 \%$ Triton X-100 (100\%). LDH activity was identified in the supernatants using the CytoTox $96^{\circ}$ Non-Radioactive Cytotoxicity Assay Kit (Promega Corporation, Madison, USA). The reaction was incubated at $25^{\circ} \mathrm{C}$ in total darkness for $30 \mathrm{~min}$. $\mathrm{LDH}$ activity was measured by absorbance at $490 \mathrm{~nm}$ using an iMarK Microplate Reader microplate reader (Bio-Rad). The percentage of cytosolic $\mathrm{LDH}$ released was calculated via the following equation:

$$
\% L D H=\left(L D H_{o b s}-L D H_{0 \%}\right) /\left(L D H_{100 \%}-L D H_{0 \%}\right) x 100
$$

\section{Anthopleura dowii venom fractionation}

A total of $720 \mathrm{mg}$ of protein contained in $200 \mathrm{~mL}$ of the crude extract was precipitated with an ammonium sulfate gradient (40\%, $50 \%, 60 \%$, and $80 \%$ of saturation) in $50 \mathrm{mM}$ phosphate buffer at $\mathrm{pH} 7.4$ and $4^{\circ} \mathrm{C}$ [46]. Each gradient was kept cold overnight and centrifuged at $25,400 \mathrm{x}$ g for $140 \mathrm{~min}$ at $4{ }^{\circ} \mathrm{C}$. Each precipitate was resuspended in $50 \mathrm{mM}$ phosphate buffer, $\mathrm{pH} 7.4$, and dialyzed against the same buffer. To remove the non-soluble protein, the dialyzed samples were centrifuged at $25,400 \mathrm{x}$ for $10 \mathrm{~min}$ at $4^{\circ} \mathrm{C}$. The samples were analyzed in $15 \%$ SDS-PAGE polyacrylamide gel [47] and their hemolytic and cytotoxic activities were measured. The fraction with the highest hemolytic and cytotoxic activities was applied to $10 \mathrm{~mL}$ DEAE Sepharose Fast Flow anion exchange chromatography (GE) column and equilibrated with $50 \mathrm{mM}$ phosphate buffer at $\mathrm{pH}$ 8.0. Elution was carried out with a step gradient of $\mathrm{NaCl}(0$, $20,40,60,80,100,200,300$ and $500 \mathrm{mM}$ ), at a flow of $1.0 \mathrm{~mL} /$ $\min$. The fractions were subjected to an electrophoretic assay in $15 \%$ polyacrylamide SDS-PAGE gel, and their hemolytic and cytotoxic activities were measured. The gel was dyed with Coomasie blue.

\section{Osmotic protection assay}

The osmotic protection assay with PEG was evaluated in A549 cells [48-50]. PEG (30 mM as final concentration) of different molecular sizes (200 Da, $400 \mathrm{Da}, 1,000 \mathrm{Da}$, and 3,350 Da) and prepared in 1X PBS solution. The cells $\left(2 \times 10^{5}\right.$ cells $\left./ \mathrm{mL}\right)$ with PEG were incubated at $37{ }^{\circ} \mathrm{C}$ and $5 \% \mathrm{CO}_{2}$ for $15 \mathrm{~min}$, and then treated with $50 \mu \mathrm{g}$ of protein. After $6 \mathrm{~h}$ of incubation, the supernatant was collected and the LDH released was calculated as mentioned above. 


\section{Sample preparation for mass spectrometry}

To remove the PBS, the sample was passed through a Sep-Pak C18 cartridge (Waters Corp., USA) and lyophilized. Subsequently, it was resuspended in $100 \mathrm{mM}$ ammonium bicarbonate $(\mathrm{pH} 8$ - 8.5) and quantified in triplicate in a NanoDrop 2000 (Thermo Scientific) at $280 \mathrm{~nm}$. The cysteine reduction was performed at $10 \mathrm{mM}$ DTT for $60 \mathrm{~min}$ at $37^{\circ} \mathrm{C}$, and alkylation was performed with $20 \mathrm{mM}$ iodocatamide for $30 \mathrm{~min}$ in darkness at room temperature. For digestion, trypsin (Promega) was used in a 1:40 w/w ratio for $4 \mathrm{~h}$ at $37^{\circ} \mathrm{C}$; Protease MAX (Promega) was added to the solution to improve solubility and promote digestion. Finally, the sample was desalted using a Sep-Pak C18, concentrated by lyophilization, and resuspended in water with $0.1 \%$ formic acid.

\section{Mass spectrometry}

Analysis by liquid chromatography was performed in a HALO C18 column of $0.3 \times 150 \mathrm{~mm}$ in the high-performance liquid chromatographer Eksigent NanoLC 400 (AB SCIEX Dublin, CA) coupled to the mass spectrometer TripleTOF 5600+ (MA, AB SCIEX Framingham, MA, USA) equipped with a DuoSpray font. The Analyst TF 1.7 program was employed to operate the equipment and acquire the data, which were collected in positive mode by electrospray ionization by applying the IDA method (information-dependent acquisition method). In the Mass spectrometry (MS), a mass range of 250 - 1500 was used and for the tandem MS (MS/MS), a range of $50-1500 \mathrm{~m} / \mathrm{z}$ was utilized. The scan lasted $120 \mathrm{~min}$ with a cycle time of $1.3 \mathrm{~s}$ and a total of 5,536 cycles. In each cycle, the maximum number of monitored ions was 20 with a tolerance of $0.1 \mathrm{Da}$. In total, two injections were made, one of $2 \mu \mathrm{g}$ and another of $6 \mu \mathrm{g}$. The mobile phases consisted of water with $0.1 \%$ formic acid (A) and acetonitrile with $0.1 \%$ formic acid (B). The separation was performed by a linear gradient of 5\% - 30\% B for $110 \mathrm{~min}$ and $30-100 \%$ B for $10 \mathrm{~min}$ with a flow of $5 \mu \mathrm{L} / \mathrm{min}$.

\section{Protein identification}

The data obtained directly from the MS were processed by the software ProteinPilot 4.5 (AB Sciex) using the Paragon algorithm to search for matches within the UniProt Anthopleura (230 entries) and Actiniidae (708 entries) databases. Trypsin was considered a digestion enzyme, idoacetamide a cysteine alkylating agent, and identification was established at $>95 \%$ probability.

\section{Statistical analysis}

The data are expressed as the mean \pm SD of three different experiments with triplicate values. An analysis of variance was utilized for the statistical analysis, and a Turkey's multiple comparison test was performed via the software OriginPro (version 9). Differences were considered statistically significant at $p$ values less than 0.05 .

\section{Results}

\section{Hemolytic and cytotoxic activities of $A$. dowii venom}

The presence of polypeptide molecules that exhibit diverse biological activities such as hemolytic and cytotoxic capacities present in sea anemone venom has been reported previously $[19,51]$. The extraction method employed to prepare the A. dowii venom allowed us to obtain a mixture of different molecules, including polypeptides with a molecular weight between $10 \mathrm{kDa}$ and $250 \mathrm{kDa}$. We detected proteins with molecular weights similar to those reported for actinoporins ( 20kDa) [15] (Figure 1A). To identify the cytolytic activity in the venom of $A$. dowii, a hemolytic assay was performed on human, rabbit, sheep, and goat erythrocytes. Our results showed that the venom has components capable of producing lysis in erythrocytes of these four mammalian species. In all cases, hemolysis tended to rise as the concentration of total protein present in the venom increased until $100 \%$ lysis. Hemolytic activity showed a significant difference between goat and sheep erythrocytes compared to human and rabbit erythrocytes. Thus, sheep erythrocyte membranes were significantly more susceptible to the hemolytic activity of the venom with a $\mathrm{HU}_{50}$ equal to $10.7 \pm 2 \mu \mathrm{g}$, whereas $50 \%$ of the goat, human and rabbit erythrocytes were lysed with $13.2 \pm 3 \mu \mathrm{g}, 25.6 \pm 0.5 \mu \mathrm{g}$ and $34.7 \pm 0.6 \mu \mathrm{g}$, respectively (Figure 1B). According to previous studies, these differences in hemolytic activity may be due to the lipid composition of the membranes from different red blood cells [24,27].

It has previously been demonstrated that the cytoplasmic membrane of tumor cells has a significantly altered composition compared to normal cells, with higher concentrations of sphingomyelin, phosphatidylinositol, and cholesterol [31,52]. Some cytolysins from sea anemones, such as actinoporins, have a high affinity for lipids including sphingomyelin or cholesterol, which is essential for its action mechanism $[24,53]$. To investigate the effect of venom on human alveolar adenocarcinoma (A549 cell line), cytotoxicity assays were performed on A549 cells with an increasing concentration of venom, and the number of living cells was determined by the trypan blue exclusion method. The venom decreased viability in a dose-dependent manner, in a protein concentration range of $0.125-50 \mu \mathrm{g} / \mathrm{mL}$. The protein concentration in the venom responsible for producing $50 \%$ death $\left(\mathrm{IC}_{50}\right)$ was equal to $1.84 \pm 0.4 \mu \mathrm{g}$ (Figure $1 \mathrm{C}$ ). In the presence of venom, contact between the cells decreased, and their polygonal form with membrane protrusions changed to a round shape. Figure $1 \mathrm{E}$ and $1 \mathrm{~F}$ show representative images of the experiments where the morphological changes of the cells are clearly observed in the presence of $50 \mu \mathrm{g}$ of total protein in the venom.

To determine whether the venom promoted cell death by causing damage to the plasma membrane, the release of $\mathrm{LDH}$ was measured. $\mathrm{LDH}$ is a stable enzyme that is removed from the cells in high quantities after plasma membrane damage has occurred, and is an indicator of necrosis [45]. Our results showed that this phenomenon is concentration-dependent. At $3.12 \pm 0.40 \mu \mathrm{g} / \mathrm{mL}$ extracellular $\mathrm{LDH}$ was not detected. However, 

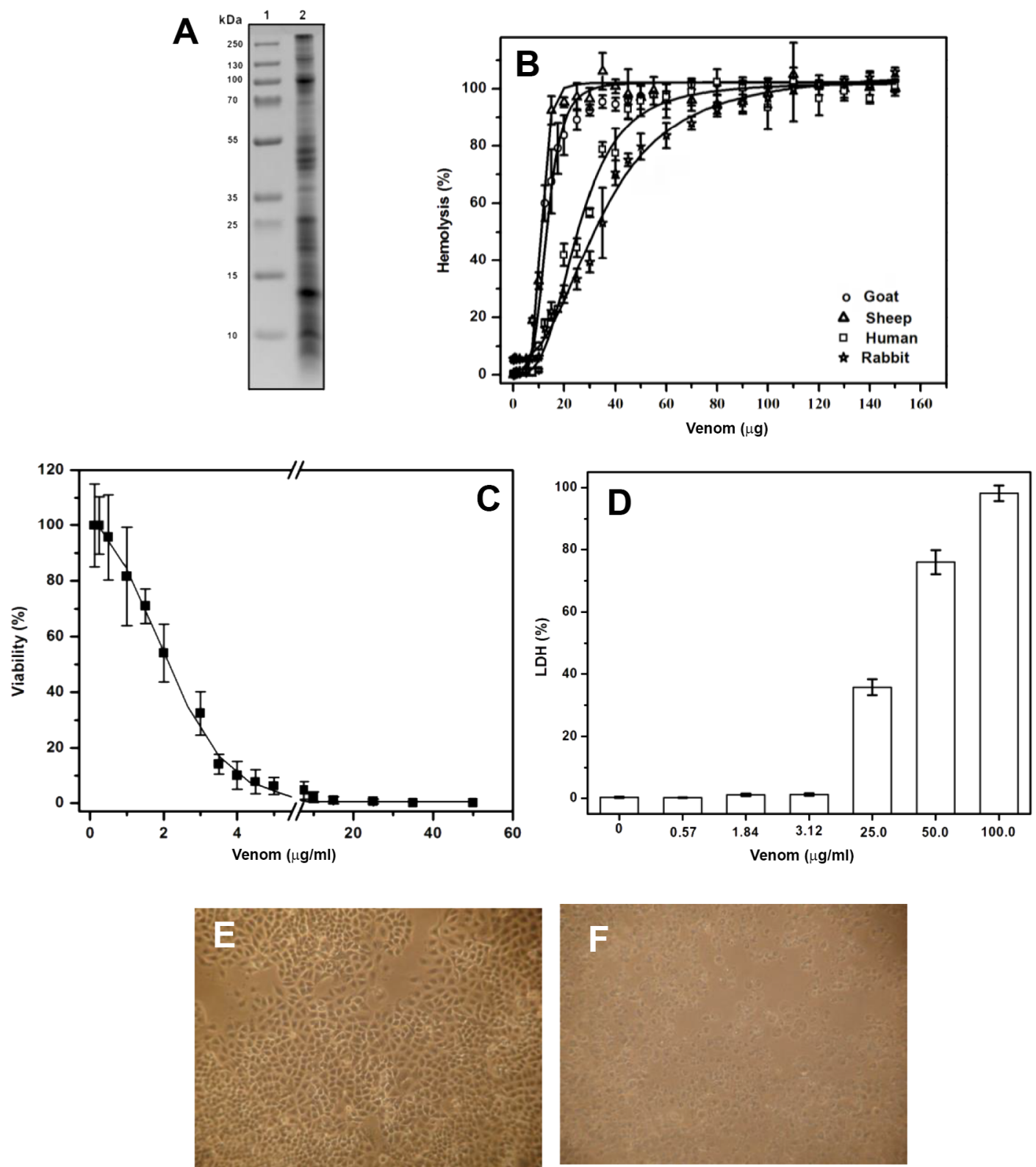

Figure 1 Characterization of A. dowii Verrill (1869) venom. A. SDS-PAGE analysis of venom, lane 1: protein molecular weight marker, lane 2: venom. B. Hemolysis produced by the venom in erythrocytes from different mammals. C. Viability assay of A549 cells exposed to different concentrations of sea anemone venom. $\mathbf{D}$. Cytotoxicity was analyzed by measuring LDH released from A549 cell line. Morphological changes of A549 cells without (E) and with (F) $50 \mu g / \mathrm{mL}$ of total protein from venom were observed via transmitted light microscopy.

concentrations of 25,50 , and $100 \mu \mathrm{g} / \mathrm{mL}$ of total protein caused LDH release (Figure 1D). These results suggest that at higher protein concentrations in the venom, the membrane integrity is compromised. These results indicate that $A$. dowii venom contains different components that induce cell death by two different mechanisms; i.e., at low concentration it could indicate apoptosis, whereas at high concentrations it may represent cell lysis.

\section{A. dowii venom fractionation}

Venom was precipitated with a gradient of ammonium sulfate. Figure 2A shows the electrophoretic pattern, and the hemolytic and cytotoxic activities of each fraction. The proteins precipitated with $60 \%$ ammonium sulfate were the only fraction that showed hemolytic activity. Apart from the proteins precipitated with $50 \%$ ammonium sulfate, the rest had cytotoxic activity. The morphology of A549 was also affected by these samples (see Additional File 1). The fraction with hemolytic activity was applied to an anion exchange column and eluted by a $\mathrm{NaCl}$ gradient (Figure 2B). Most proteins did not bind to the column. All fractions were analyzed in a $15 \%$ polyacrylamide gel SDSPAGE and their activities were measured. The F1 fraction was the only one that presented hemolytic and cytotoxic activities (Figures 2C, 2B, and 2E). F1 and F2 fractions (Figure 2C) produced similar morphological changes in A549 cells and LDH 

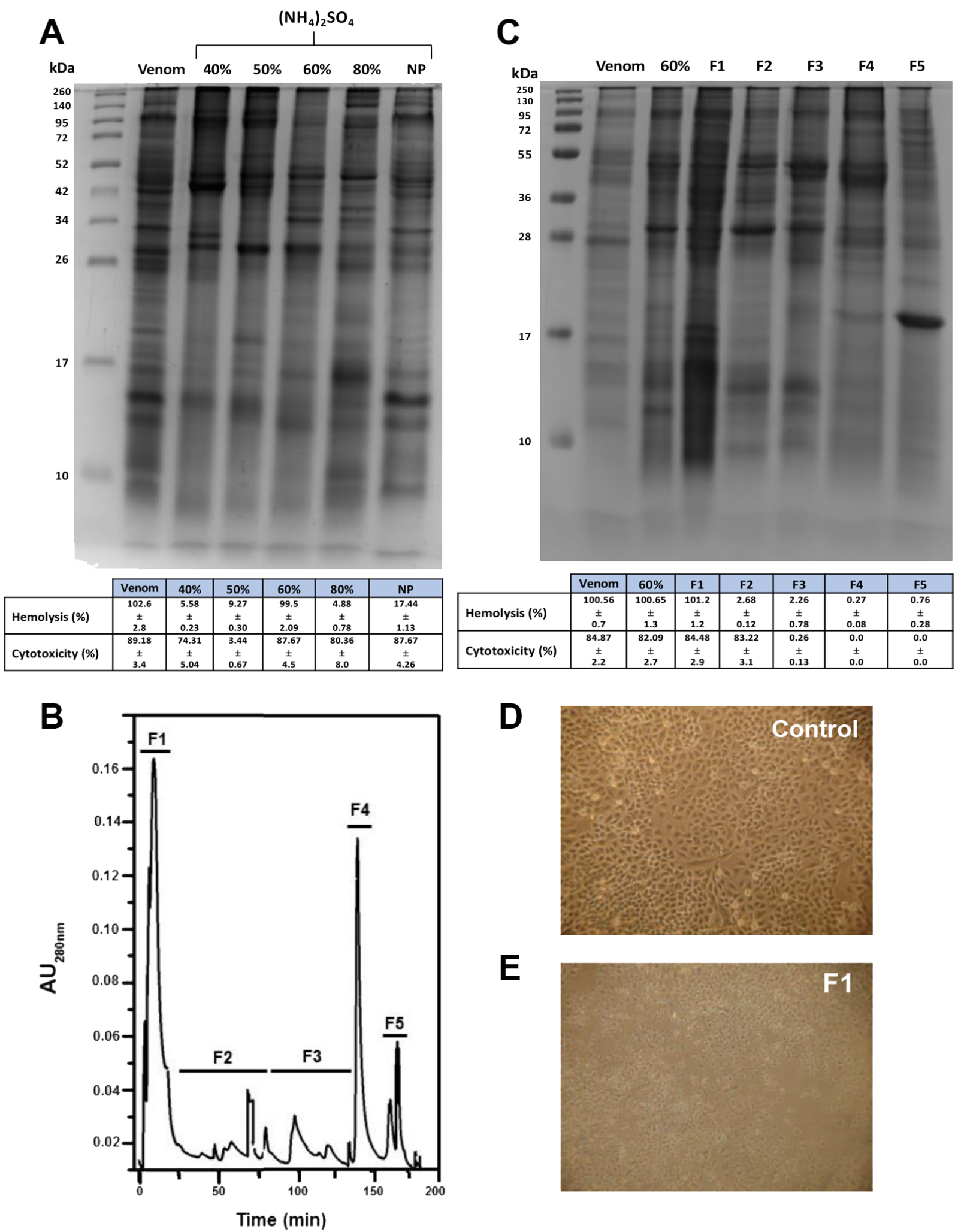

$\mathbf{E}$

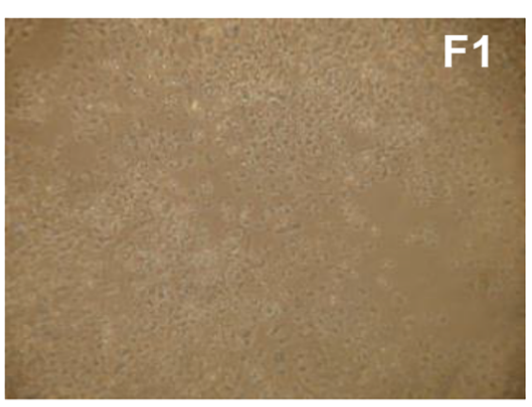

Figure 2 Venom fractionation. A. Gradual precipitation of venom with ammonium sulfate. SDS-PAGE, hemolytic activity in human red blood cells, and cytotoxicity in A549 cells determined by released LDH. B. Anion exchange chromatography of proteins precipitated with $60 \%$ ammonium sulfate. Five fractions were obtained by chromatography (F1: $0 \mathrm{mM} \mathrm{NaCl}, \mathrm{F} 2: 20-60 \mathrm{mM} \mathrm{NaCl}, \mathrm{F} 3: 80-100 \mathrm{mM} \mathrm{NaCl}, \mathrm{F} 4: 200 \mathrm{mM} \mathrm{NaCl}, \mathrm{F} 5: 300 \mathrm{mM} \mathrm{NaCl}$ ). C: Denaturing electrophoresis of the fractions obtained in B, hemolytic activity in human erythrocytes and cytotoxicity in A549. D and E: A549 cells without and with F1, respectively. 
in relation to those observed with whole venom (see Additional File 1).

\section{Damage to plasma membrane in the A549 cell line by pore formation}

Sea anemones produce a class of proteins that can alter the cell membrane through pore-formation that provokes cellular lysis by osmotic imbalance [54]. This can be countered by the use of osmotic protectants such as PEG $[55,56]$. To determine whether proteins from the F1 fraction produced damage to A549 cells because of pore formation, the percent of osmotic protection was determined based on LDH released after PEG treatment in the presence or absence of $50 \mu \mathrm{g}$ of total protein. As shown in Figure 3A, osmoprotectant PEG $200 \mathrm{Da}, 400 \mathrm{Da}$, and 1,000 Da were significantly different compared with PEG 3,350 Da. The $\mathrm{LDH}$ activity was reduced by $100 \%$ only in the presence of PEG 3,350 Da. As shown in Figures 3B, 3C and 3D, the osmotic protection from $\mathrm{PEG}$ in the presence of the $\mathrm{F} 1$ fraction derived from A549 cells preserved their polygonal morphology. This result shows that the cytotoxic activity of the F1 fraction could be due to the presence of pore formation. To corroborate this,
F1 was analyzed by mass spectrometry to identify the presence of a pore-forming protein.

\section{Polypeptides identified in F1 fraction by MS / MS}

The F1 fraction was processed by MS to explore its polypeptide composition. Data were processed by the software ProteinPilot 4.5 (AB Sciex) using the cured (UniprotKB/Swiss-Prot) and uncured databases (UniprotKB / TrEMBL) of Anthopleura (https:// www.uniprot.org/uniprot/?query=Anthopleura\&sort=score) with 230 total entries and Actiniidae with 708 total UniProt entries during September 2018 (https://www.uniprot.org/ uniprot/?query=Actiniidae+\&sort=score). A total of 35 polypeptides with molecular weight between 4 and $80 \mathrm{kDa}$ were identified in the protein sample from the tryptic peptides from F1 (see Additional Files 2 and 3). The identified proteins were grouped according to their function and their relative abundances were calculated (Figure 4A). The components mostly represented in the F1 fraction corresponded to $\mathrm{Na}+$ toxins (17\%). Other components related to the sea anemone venom included $\mathrm{K}+$ toxins with inhibitory activity of Kunitz type proteases and toxins of family 8 (see Additional File 2). Only one actinoporin

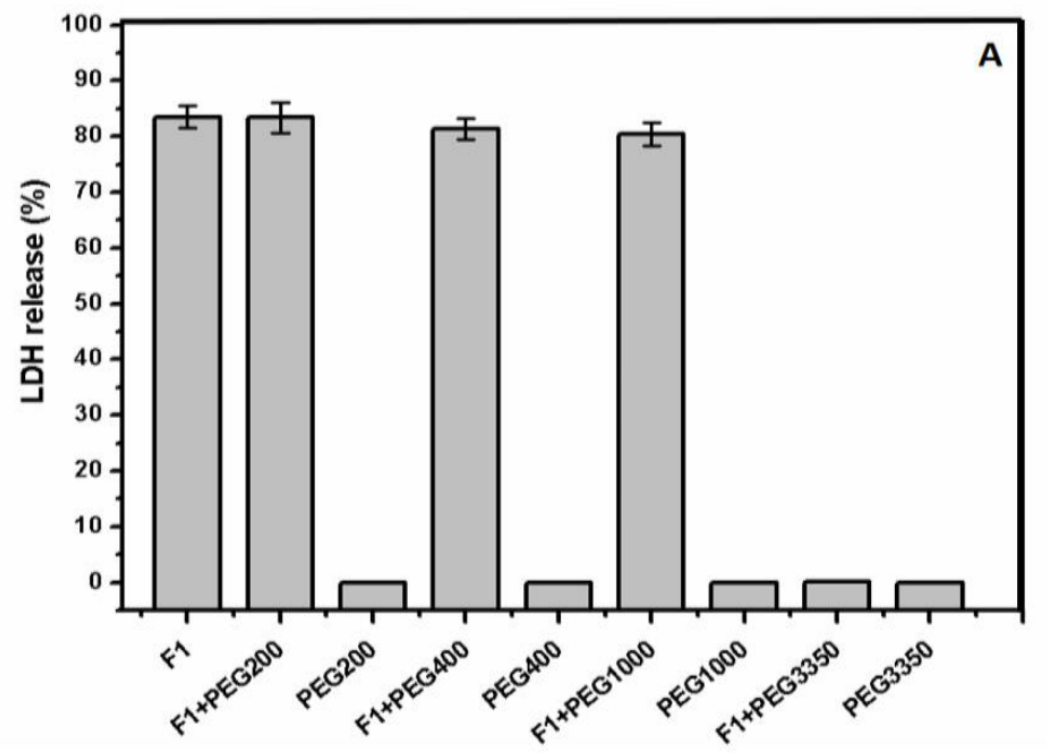

B

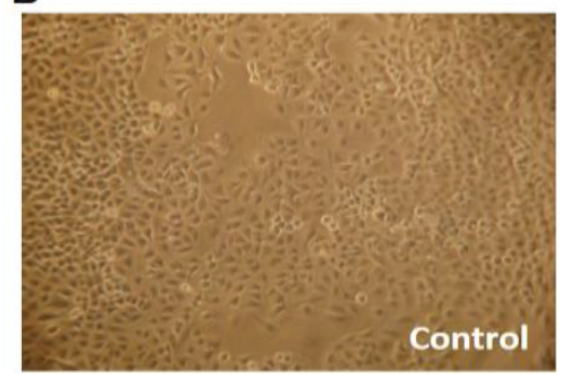

C

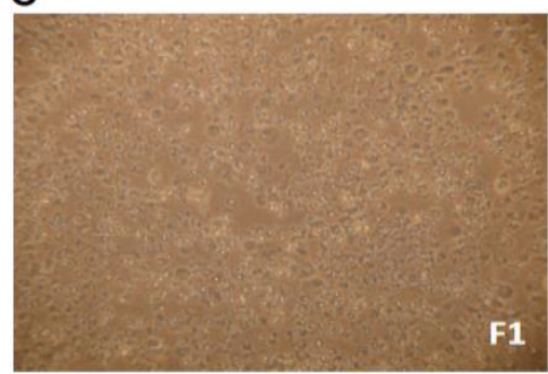

D

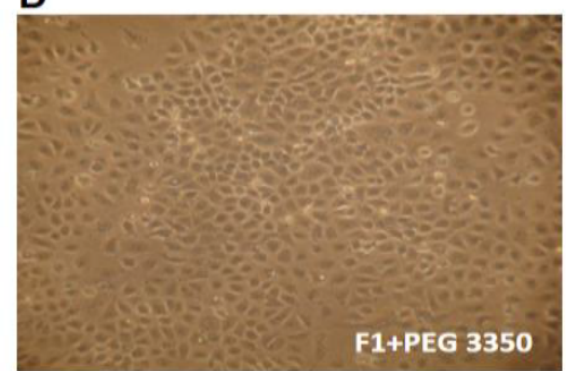

Figure 3. PEG as osmotic protectants in A549 cells in the presence of F1 fraction. A. Cells were previously incubated with different PEG before adding $50 \mu \mathrm{g}$ of F1 fraction. The buffer used was $50 \mathrm{mM}$ phosphate, $\mathrm{pH} 7.4$. B, C and $\mathbf{D}$ : Damage to the cells by $50 \mu \mathrm{g} / \mathrm{mL}$ of the F1 fraction was inhibited by the addition of PEG 3,350. 

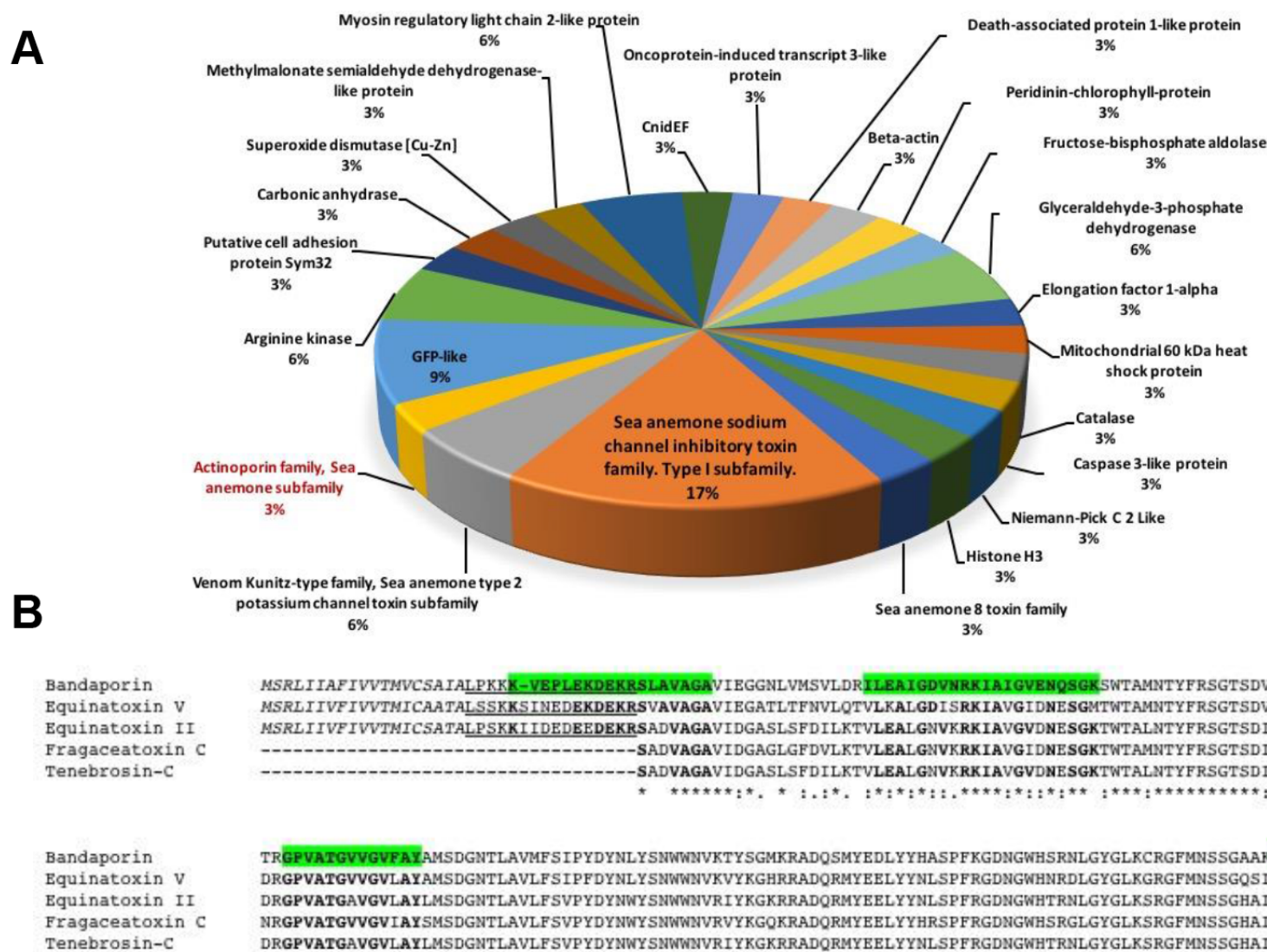

MSRL I IAFIVVTMVCSA IALPKKK K-VEPLEKDEKRSLAVAGAVIEGGNLVMSVLDRILEAIGDVNRKIAIGVENQSGKSWTAMNTYFRSGTSDVVLPHSVPSGKALLYDGQK MSRLI IVF IVVTMICAATALSSKKSINEDEKDEKRSVAVAGAVIEGATLTFNVLOTVLKALGDISRKIAVGIDNESGMTWTAMNTYFRSGTSDVILPHTVPHGKALLYNGQK MSRLIIVF IVVTMICSATALPSKKIIDEDEEDEKRSADVAGAVIDGASLSFDILKTVLEALGNVKRKIAVGVDNESGKTWTALATYFRSGTSDIVLPHKVPHGKALLYNGQK SADVAGAVIDGASLSFDILKTVLEALGNVKRKIAVGVDNESGKTWTALATYFRSGTSDIVLPHKVPHGKALLYNGQK

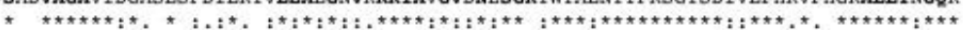

Figure 4 Distribution of the components identified by MS / MS in the F1 fraction and multiple alignment of actinoporins showing the region covered by the tryptic peptides. A. Relative proportions of the polypeptides identified using the Anthopleura and Actiniidae databases from UniprotKB. B. Multiple alignment of bandaporin (DELTA-actitoxin-Aas1a) from Anthopleura asiatica, Equinatoxin II (DELTA-actitoxin-Aeq1a) and V (DELTA-actitoxin-Aeq1b) from Actinia equina, Fragaceatoxin-C (DELTA-actitoxin-Afr1a) from Actinia fragacea and Tenebrosin-C (DELTA-actitoxin-Ate1a) from Actinia tenebrosa. The region covered by the triptych peptides in the bandaporin sequence is highlighted in green. In all sequences, the residues conserved with the region covering the tryptic peptides appear in boldface. The signal peptide is in italics and the propeptide region is underlined.

was identified in the F1 fraction, for which $32 \%$ coverage was obtained with respect to DELTA-actitoxin-Aasla (Figure 4B). The remainder of the proteins identified in the $\mathrm{F} 1$ fraction were proteins not related to toxic function and those that have been reported in other species of sea anemones, such as enzymatic proteins (e.g., superoxide dismutase, carbonic anhydrase), enzymes related to the metabolism of carbohydrates, arginine kinases, structural proteins, and adhesion and stress proteins.

At least 13 tryptic peptides that align with regions of the reported protein such as bandaporin (DELTA-actitoxin-Aasla) were identified in the F1 fraction (see Additional File 2) covering $32 \%$ of the amino acid sequence. Bandaporin has previously been isolated from $A$. asiatica whereas its hemolytic activity on sheep erythrocytes $\left(\mathrm{EC}_{50}\right.$ of $\left.8.8 \mathrm{ng} / \mathrm{mL}\right)$ and lethal toxicity $\left(\mathrm{LD}_{100}\right.$ equal to $0.58 \mathrm{mg} / \mathrm{kg}$ ) were estimated in crayfish [57]. Figure $4 \mathrm{~B}$ shows the alignment of bandaporin with four other actinoporins. The region covered by the triptych peptides was identified (Figure 4B, green colored region) in the F1 fraction, which showed $100 \%$ identity with the bandaporin sequence with respect to the other four actinoporins present in the alignment. The identity percentage (\% I) was calculated via the software LALIGN (https://embnet.vital-it.ch/software/LALIGN_form. html) considering only the mature regions of all proteins. Alignment was accomplished using the software ClustalX (2.0).

\section{Discussion}

Sea anemone venom is a complex mixture of molecules with different targets and diverse biological functions (e.g., neurotoxins, phospholipases, cytolysin, protease inhibitors, antimicrobial peptides, and lectins). The main interest in the investigation of these molecules is to isolate and characterize candidates potentially useful for the development of new drugs $[1,7]$. The present study showed the identification of a pore-forming protein in the A. dowii venom. Among proteins previously described in sea anemones to have pore-forming capacity, actinoporins stand out owing to their proven ability 
to form pores in the cell membrane, which are directly responsible for osmotic imbalance and cell death $[15,58]$. The membrane-binding activity of actinoporins depends on the lipid composition, while a high concentration of sphingomyelin has been proven to facilitate pore formation $[24,59,60]$. The lipid compositions differ significantly among goat, sheep, rabbit and human erythrocytes, especially in their sphingomyelin content $[62,63]$. The hemolytic activity results produced by the A. dowii venom showed that the erythrocytes with the highest amount of sphingomyelin were from the sheep, which were more sensitive to the cytolytic effect produced by proteins in the venom. It has recently been reported that the activity of four actinoporins (equinatoxin II, fragaceatoxin C and sticholysins I and II) have different activities that present variations in the composition of lipids and biophysics membrane [24].

One method of studying in vitro cytotoxicity is by measuring LDH leakage. This assay indicates the permeability increase of the membrane as a consequence of damage to its structure, resulting in the release of intracellular components and subsequent cell death [63]. The release of intracellular LDH demonstrated that the protein components of the venom and F1 fraction were capable of inducing A549 cells lysis. Further studies are required to determine the mechanism by which cell death occurred. In the sea anemone Heteractis magnifica venom was reported to produce necrosis in A549 cells, and this was determined by mitochondrial membrane potential [12]. The A549 cell viability was reduced by approximately $70 \%$ when using $3.5 \mu \mathrm{g}$ of $A$. dowii venom as determined by the trypan blue exclusion assay. The fact that at this concentration no LDH activity was detected in the supernatants indicates that, in addition to cell membrane damage and cytolysis, the $A$. dowii venom was able to induce cell death by a distinct mechanism, but this must still be tested. The morphological changes observed in A549 cells are similar of those observed in Raji and L1210 cells exposed to Sticholysin II and to Nigrelysin respectively [64,65], these two actinoporins cause an increase in cell volume, loss of polygonal shape and subsequent lysis. However, a cell death process, such as pyroptosis or the phenomenon of cell lysis, can be an independent event, as has been reported in macrophages from mouse bone marrow, in which pyroptotic cell death was observed to be an independent event preceding cell lysis [66].

Owing to the presence of properties that can recognize and permeabilize plasma membrane, these pores have a medical potential and application in challenging cell proliferation such as in cancer therapy. Based on previous studies, it has been proposed that specific immunotoxins be constructed using a conjugate of monoclonal antibodies and cytolysin from sea anemones [36]. The main advantage of immunotoxins composed of anemones cytolysins is that they do not need to be applied directly in the intracellular space to destroy a particular neoplasm $[18,36]$.

The integrity of the plasma membrane is crucial for proper cellular function and stability. The pores produced by actinoporins produce an ionic imbalance or uncontrolled flow and permeabilization to a variety of molecules that depend on the pore size $[55,67]$. Our results have shown that damage to the plasma membrane of A549 cells may be the result of pores formed by proteins. The osmotic lysis generated by the formation of pores in the plasma membrane can be avoided by the use of osmolytes such as PEG, which prevent cytoplasmic components such as LDH from being released [40]. Our results allowed us to observe a remarkable reduction of lysis in A549 cells by adding PEG of 3,350 Da, whereas the damage to the cell membrane appeared to occur through the action of a pore-forming protein present in the A. dowii venom and F1 fraction. These results are consistent with the fact that PEG can inhibit the hemolysis produced by pore-forming proteins [68].

Because of the complexity of the $A$. dowii venom shown in the data obtained during fractionation, we propose a more detailed analysis of the fractions obtained in the precipitation with ammonium sulfate ( $40 \%, 80 \%$, and not precipitated), principally fractions with high cytotoxic activity in A549 cells, and very low hemolytic activity. This indicates the presence of more than one molecule with possible antitumor potential in A. dowii venom.

\section{Conclusions}

A. dowii venom contains at least one polypeptide with the ability to lyse cells by the pore-formation mechanism in the plasma membrane of the A549 cell line. This molecule should be considered in the design of drugs for cancer therapy, with future investigations required to analyze their action mechanism.

\section{Acknowledgments}

We are grateful to Samanta Jiménez, Nilda del Carmen Sánchez Castellanos, Jonathan Salazar León, María Elena Elizabeth Mata Moreno, and Juan Manuel Barbosa Castillo for technical assistance.

\section{Abbreviations}

$\mathrm{HU}_{50}$ : the protein concentration in the venom that produced $50 \%$ hemolysis; $\mathrm{IC}_{50}$ : the amount of protein present in the venom responsible for producing 50\% death in A549 cells.

\section{Availability of data and material}

All data generated are included in supplementary information files.

\section{Funding}

This work was supported by Consejo Nacional de Ciencia y Tecnología (CONACyT), México, with a grant number 178151, and by Programa de Apoyo a Proyectos de Investigación e Innovación Tecnológica (PAPIIT), with a grant number IT200819. Santos Ramírez Carreto is a student enrolled in the Doctoral Degree Program in Biochemical Sciences-UNAM, supported by the CONACyT México scholarship number 404279. Moreover, this publication was supported by the Coordination for the Improvement of Higher Education Personnel (CAPES) 
through “Programa Editoração CAPES” - call No. 3/2016, grant No. 0722/2017, record No. 88881.142062/2017-01 and by the National Council for Scientific and Technological Development (CNPq) and Coordination for the Improvement of Higher Education Personnel (CAPES) through "Programa Editorial CNPq/CAPES” call No. 18/2018, grant No. 404770/2018-5.

\section{Competing interest}

The authors declare that they have no competing interest in relation to the publication of this paper.

\section{Authors' Contributions}

CRA, GPA, SRC and LPM conceived and designed the experiments. SRC, EIPG, CRA and SISG performed the experiments. CRA, SRC, JBS and GPA analyzed the data. CRA, SRC, EIPG, ERP, ALN, GPA and LPM wrote the paper.

\section{Ethics approval and consent to participate}

All experiments using organisms were approved by the Bioethics Committee of the Instituto de Biotecnología, Universidad Nacional Autónoma de México. In the case of the assay with erythrocytes from a human, a healthy donor agreed and gave consent before participating in the study. Rabbit blood was obtained from the Instituto de Biotecnología, Universidad Nacional Autónoma de México biotherium. Sheep and goat blood samples were purchased from the Centro de Enseñanza Práctica e Investigación en Producción y Salud Animal (CEPIPSA), UNAM. Specimens were collected according to the guidelines of the National Commission of Aquaculture, Fishing, and Feeding of the Mexican Federal Government (permit number PPF/ DGOPA 07332.250810.4060).

\section{Consent for publication}

Not applicable.

\section{Supplementary material}

The following online material is available for this article

Additional File 1: The morphological change in A549 cells is demonstrated by the protein precipitation with different concentrations of ammonium sulfate (A) and with the fractions obtained in the anion exchange chromatography (B). (pdf $113 \mathrm{~kb}$ )

Additional File 2: Peptides and proteins identified in the F1 fraction of the venom of Anthopleura dowii using LC - MS/MS. (pdf $138 \mathrm{~kb}$ ).

Additional File 3: ProteinPilot v 4.5 software program (AB Sciex) report of the tryptic peptides obtained from the F1 fraction ( $2 \mu \mathrm{g}$ and $6 \mu \mathrm{g}$ analyzed) and used for the identification of the protein components present in the sample using the Anthopleura and Actiinidae cured databases (UniprotKB/Swiss-Prot).

\section{References}

1. Lebbe EKM, Tytgat J. In the picture: disulfide-poor conopeptides, a class of pharmacologically interesting compounds. J Venom Anim Toxins Incl Trop Dis. 2016;22(1):30. Availale from: https://doi.org/10.1186/ s40409-016-0083-6

2. Genikhovich G, Technau U. On the evolution of bilaterality. Development. 2017;144(19):3392-3404. Availale from: https://doi. org/10.1242/dev.141507

3. Park E, Hwang D-S, Lee J-S, Song J-I, Seo T-K, Won Y-J. Estimation of divergence times in cnidarian evolution based on mitochondrial proteincoding genes and the fossil record. Mol Phylogenet Evol. 2012;62(1):329345. Availale from: https://doi.org/10.1016/j.ympev.2011.10.008

4. Fautin DG. Structural diversity, systematics, and evolution of cnidae. Toxicon. 2009;54(8):1054-1064. Availale from: https://doi.org/10.1016/j. toxicon.2009.02.024

5. Rachamim T, Morgenstern D, Aharonovich D, Brekhman V, Lotan T, Sher D. The dynamically evolving nematocyst content of an anthozoan, a scyphozoan, and a hydrozoan. Mol Biol Evol. 2015;32(3):740-753. Availale from: https://doi.org/10.1093/molbev/msu335

6. Jouiaei M, Yanagihara AA, Madio B, Nevalainen TJ, Alewood PF, Fry BG. Ancient Venom Systems: A Review on Cnidaria Toxins. Toxins (Basel). 2015;7(6):2251-2271. Availale from:https://doi.org/10.3390/ toxins7062251

7. Frazão B, Vasconcelos V, Antunes A. Sea anemone (Cnidaria, Anthozoa, Actiniaria) toxins: an overview. Mar Drugs. 2012;10(12):1812-1851. Availale from: https://doi.org/10.3390/md10081812.

8. Logashina YA, Solstad RG, Mineev KS, et al. New Disulfide-Stabilized Fold Provides Sea Anemone Peptide to Exhibit Both Antimicrobial and TRPA1 Potentiating Properties. Toxins (Basel). 2017;9(5):9. Availale from: https://doi.org/10.3390/toxins9050154

9. Uechi G-I, Toma H, Arakawa T, Sato Y. Biochemical and physiological analyses of a hemolytic toxin isolated from a sea anemone Actineria villosa. Toxicon. 2005;45(6):761-766. Availale from: https://doi. org/10.1016/j.toxicon.2005.01.015

10. Hu B, Guo W, Wang L-H, Wang J-G, Liu X-Y, Jiao B-H. Purification and characterization of gigantoxin-4, a new actinoporin from the sea anemone Stichodactyla gigantea. Int J Biol Sci. 2011;7(6):729-739. Availale from: https://doi.org/10.7150/ijbs.7.729.

11. Ständker L, Béress L, Garateix A, et al. A new toxin from the sea anemone Condylactis gigantea with effect on sodium channel inactivation. Toxicon. 2006;48(2):211-220. Availale from: https://doi.org/10.1016/j. toxicon.2006.05.001

12. Ramezanpour M, da Silva KB, Sanderson BJS. Venom present in sea anemone (Heteractis magnifica) induces apoptosis in non-small-cell lung cancer A549 cells through activation of mitochondria-mediated pathway. Biotechnol Lett. 2014;36(3):489-495. Availale from: https:// doi.org/10.1007/s10529-013-1402-4

13. Marino $A$, Valveri $V$, Muià $C$, et al. Cytotoxicity of the nematocyst venom from the sea anemone Aiptasia mutabilis. Comp Biochem Physiol C Toxicol Pharmacol. 2004;139(4):295-301. Availale from: https://doi. org/10.1016/j.cca.2004.12.008

14. Komatsu S, Furukawa K, Abe K, Hirano H, Ueda M. Isolation and characterization of equinatoxins from the sea anemone Actinia equina L. Chem Pharm Bull (Tokyo). 1992;40(10):2873-2875. Availale from: https://doi.org/10.1248/cpb.40.2873

15. Podobnik M, Anderluh G. Pore-forming toxins in Cnidaria. Semin Cell Dev Biol. 2017;72:133-141. Availale from: https://doi.org/10.1016/j. semcdb.2017.07.026

16. Norton RS. Structures of sea anemone toxins. Toxicon. 2009;54(8):10751088. Availale from: https://doi.org/10.1016/j.toxicon.2009.02.035

17. Blanchard MG, Rash LD, Kellenberger S. Inhibition of voltage-gated $\mathrm{Na}(+)$ currents in sensory neurones by the sea anemone toxin APETx2. Br J 
Pharmacol. 2012;165(7):2167-2177. Availale from: https://doi.org/10.1111/ j.1476-5381.2011.01674.x

18. Lv X, Zhang J, Xu R, et al. Gigantoxin-4-4D5 scFv is a novel recombinant immunotoxin with specific toxicity against HER2/neu-positive ovarian carcinoma cells. Appl Microbiol Biotechnol. 2016;100(14):6403-6413. Availale from: https://doi.org/10.1007/s00253-016-7487-7

19. Mariottini GL, Pane L. Cytotoxic and cytolytic cnidarian venoms. A review on health implications and possible therapeutic applications. Toxins (Basel). 2013;6(1):108-151. Availale from: https://doi.org/10.3390/ toxins6010108

20. Prentis PJ, Pavasovic A, Norton RS. Sea Anemones: Quiet Achievers in the Field of Peptide Toxins. Toxins (Basel). 2018;10. Availale from: https://doi.org/10.3390/toxins10010036

21. Lazcano-Pérez F, Zavala-Moreno A, Rufino-González Y, et al. Hemolytic, anticancer and antigiardial activity of Palythoa caribaeorum venom. J Venom Anim Toxins Incl Trop Dis. 2018;24(1):12. Availale from: https:// doi.org/10.1186/s40409-018-0149-8

22. Oliveira CS, Caldeira CAS, Diniz-Sousa R, et al. Pharmacological characterization of cnidarian extracts from the Caribbean Sea: evaluation of anti-snake venom and antitumor properties. J Venom Anim Toxins Incl Trop Dis. 2018;24(1):22. Availale from: https://doi.org/10.1186/ s40409-018-0161-z

23. Anderluh G, Macek P. Cytolytic peptide and protein toxins from sea anemones (Anthozoa: actiniaria). Toxicon. 2002;40(2):111-124. Availale from: https://doi.org/10.1016/S0041-0101(01)00191-X

24. García-Linares S, Rivera-de-Torre E, Morante K, et al. Differential Effect of Membrane Composition on the Pore-Forming Ability of Four Different Sea Anemone Actinoporins. Biochemistry. 2016;55(48):66306641. Available from: https://doi.org/10.1021/acs.biochem.6b01007

25. Rojko N, Dalla Serra M, Maček P, Anderluh G. Pore formation by actinoporins, cytolysins from sea anemones. Biochim Biophys Acta. 2016;1858(3):446-456. Available from: https://doi.org/10.1016/j. bbamem.2015.09.007

26. Tanaka K, Caaveiro JMM, Morante K, González-Mañas JM, Tsumoto K. Structural basis for self-assembly of a cytolytic pore lined by protein and lipid. Nat Commun. 2015;6(1):6337. Available from: https://doi. org/10.1038/ncomms7337

27. Wacklin HP, Bremec BB, Moulin M, et al. Neutron reflection study of the interaction of the eukaryotic pore-forming actinoporin equinatoxin II with lipid membranes reveals intermediate states in pore formation. Biochim Biophys Acta. 2016;1858(4):640-652. Available from: https:// doi.org/10.1016/j.bbamem.2015.12.019

28. Morante K, Bellomio A, Gil-Cartón D, et al. Identification of a Membranebound Prepore Species Clarifies the Lytic Mechanism of Actinoporins. J Biol Chem. 2016;291(37):19210-19219. Available from: https://doi. org/10.1074/jbc.M116.734053

29. García-Sáez AJ, Buschhorn SB, Keller H, Anderluh G, Simons K, Schwille P. Oligomerization and pore formation by equinatoxin II inhibit endocytosis and lead to plasma membrane reorganization. J Biol Chem. 2011;286(43):37768-37777. Available from: https://doi.org/10.1074/jbc. M111.281592

30. Cabezas S, Ho S, Ros U, Lanio ME, Alvarez C, van der Goot FG. Damage of eukaryotic cells by the pore-forming toxin sticholysin II: consequences of the potassium efflux. Biochim Biophys Acta. 2017;1859(5):982-992. Available from: https://doi.org/10.1016/j.bbamem.2017.02.001

31. Hendrich $A B$, Michalak $K$. Lipids as a target for drugs modulating multidrug resistance of cancer cells. Curr Drug Targets. 2003;4(1):2330. Available from: https://doi.org/10.2174/1389450033347172

32. Pallarés-Trujillo J, López-Soriano FJ, Argilés JM. Lipids: A key role in multidrug resistance? [Review]. Int J Oncol. 2000;16:783-798. Available from: https://doi.org/10.3892/ijo.16.4.783

33. Kristan KC, Viero G, Dalla Serra M, Macek P, Anderluh G. Molecular mechanism of pore formation by actinoporins. Toxicon. 2009;54(8):11251134. Available from: https://doi.org/10.1016/j.toxicon.2009.02.026

34. Athanasiadis A, Anderluh G, Macek P, Turk D. Crystal structure of the soluble form of equinatoxin II, a pore-forming toxin from the sea anemone Actinia equina. Structure. 2001;9(4):341-346. Available from: https://doi.org/10.1016/S0969-2126(01)00592-5

35. Tejuca M, Díaz I, Figueredo R, et al. Construction of an immunotoxin with the pore forming protein Stl and ior $\mathrm{C} 5$, a monoclonal antibody against a colon cancer cell line. Int Immunopharmacol. 2004;4(6):731-744. Available from: https://doi.org/10.1016/j.intimp.2004.02.010

36. Tejuca M, Anderluh G, Dalla Serra M. Sea anemone cytolysins as toxic components of immunotoxins. Toxicon. 2009;54(8):1206-1214. Available from: https://doi.org/10.1016/j.toxicon.2009.02.025

37. Denisenko TV, Budkevich IN, Zhivotovsky B. Cell death-based treatment of lung adenocarcinoma. Cell Death Dis. 2018;9(2):117. Available from: https://doi.org/10.1038/s41419-017-0063-y

38. Liang $X$, Huang $Y$. Physical state changes of membrane lipids in human lung adenocarcinoma $A(549)$ cells and their resistance to cisplatin. Int J Biochem Cell Biol. 2002;34(10):1248-1255. Available from: https://doi. org/10.1016/S1357-2725(02)00056-0

39. Ayala-Sumuano J-T, Licea-Navarro A, Rudiño-Piñera E, Rodríguez E, Rodríguez-Almazán C. Sequencing and de novo transcriptome assembly of Anthopleura dowii Verrill (1869), from Mexico. Genom Data. 2017;11:92-94. Available from: https://doi.org/10.1016/j.gdata.2016.11.022

40. Kem WR, Parten B, Pennington MW, Price DA, Dunn BM. Isolation, characterization, and amino acid sequence of a polypeptide neurotoxin occurring in the sea anemone Stichodactyla helianthus. Biochemistry. 1989;28(8):3483-3489. Available from: https://doi.org/10.1021/ bi00434a050

41. Bradford MM. A rapid and sensitive method for the quantitation of microgram quantities of protein utilizing the principle of protein-dye binding. Anal Biochem. 1976;72(1-2):248-254. Available from: https:// doi.org/10.1016/0003-2697(76)90527-3

42. Schägger $\mathrm{H}$, von Jagow $\mathrm{G}$. Tricine-sodium dodecyl sulfate-polyacrylamide gel electrophoresis for the separation of proteins in the range from 1 to 100 kDa. Anal Biochem. 1987;166(2):368-379. Available from: https:// doi.org/10.1016/0003-2697(87)90587-2

43. Rodriguez-Almazan C, Ruiz de Escudero I, Cantón PE, et al. The amino- and carboxyl-terminal fragments of the Bacillus thuringensis Cyt1Aa toxin have differential roles in toxin oligomerization and pore formation. Biochemistry. 2011;50(3):388-396. Available from: https:// doi.org/10.1021/bi101239r

44. Strober W. Trypan Blue Exclusion Test of Cell Viability. Curr Protoc Immunol. 2015;111:A3.B.1-3. Available from: https://doi. org/10.1002/0471142735.ima03bs111

45. Chan FK-M, Moriwaki K, De Rosa MJ. Detection of necrosis by release of lactate dehydrogenase activity. Methods Mol Biol. 2013;979:65-70. Available from: https://doi.org/10.1007/978-1-62703-290-2_7

46. Burgess RR. Protein precipitation techniques. Methods Enzymol. 2009;463:331-342. Available from: https://doi.org/10.1016/S00766879(09)63020-2

47. Laemmli UK. Cleavage of structural proteins during the assembly of the head of bacteriophage T4. Nature. 1970;227(5259):680-685. Available from: https://doi.org/10.1038/227680a0

48. Fink SL, Bergsbaken T, Cookson BT. Anthrax lethal toxin and Salmonella elicit the common cell death pathway of caspase-1-dependent pyroptosis via distinct mechanisms. Proc Natl Acad Sci USA. 2008;105(11):43124317. Available from: https://doi.org/10.1073/pnas.0707370105

49. Smith J, Manoranjan J, Pan M, et al. Evidence for pore formation in host cell membranes by ESX-1-secreted ESAT-6 and its role in Mycobacterium marinum escape from the vacuole. Infect Immun. 2008;76(12):5478-5487. Available from: https://doi.org/10.1128/IAI.00614-08

50. Dacheux D, Goure J, Chabert J, Usson Y, Attree I. Pore-forming activity of type III system-secreted proteins leads to oncosis of Pseudomonas aeruginosa-infected macrophages. Mol Microbiol. 2001;40(1):76-85. Available from: https://doi.org/10.1046/j.1365-2958.2001.02368.x

51. Monroy-Estrada HI, Chirino YI, Soria-Mercado IE, Sánchez-Rodríguez J. Toxins from the Caribbean sea anemone Bunodeopsis globulifera increase cisplatin-induced cytotoxicity of lung adenocarcinoma cells. J Venom Anim Toxins Incl Trop Dis. 2013;19(1):12. Available from: https:// doi.org/10.1186/1678-9199-19-12 
52. He M, Guo S, Ren J, Li Z. In Situ Characterizing Membrane Lipid Phenotype of Human Lung Cancer Cell Lines Using Mass Spectrometry Profiling. J Cancer. 2016;7(7):810-816. Available from: https://doi. org/10.7150/jca.14310

53. Razpotnik A, Krizaj I, Kem WR, Macek P, Turk T. A new cytolytic protein from the sea anemone Urticina crassicornis that binds to cholesteroland sphingomyelin-rich membranes. Toxicon. 2009;53(7-8):762-769. Available from: https://doi.org/10.1016/j.toxicon.2009.02.007

54. Celedon G, Venegas F, Campos AM, et al. Role of endogenous channels in red blood cells response to their exposure to the pore forming toxin Sticholysin II. Toxicon. 2005;46(3):297-307. Available from: https://doi. org/10.1016/j.toxicon.2005.04.017

55. Casallanovo F, de Oliveira FJF, de Souza FC, et al. Model peptides mimic the structure and function of the $\mathrm{N}$-terminus of the pore-forming toxin sticholysin II. Biopolymers. 2006;84(2):169-180. Available from: https:// doi.org/10.1002/bip.20374

56. Duret G, Delcour AH. Size and dynamics of the Vibrio cholerae porins $\mathrm{OmpU}$ and $\mathrm{OmpT}$ probed by polymer exclusion. Biophys J. 2010;98(9):1820-1829. Available from: https://doi.org/10.1016/j. bpj.2010.01.010

57. Kohno $Y$, Satoh H, Iguchi A, Nagai H. Characterization of a new hemolytic protein toxin from the sea anemone Anthopleura asiatica. Fish Sci. 2009 Available from: https://doi.org/10.1007/s12562-009-0112-2

58. Alvarez C, Ros U, Valle A, et al. Biophysical and biochemical strategies to understand membrane binding and pore formation by sticholysins, pore-forming proteins from a sea anemone. Biophys Rev. 2017;9(5):529544. Available from: https://doi.org/10.1007/s12551-017-0316-0

59. Schön P, García-Sáez AJ, Malovrh P, Bacia K, Anderluh G, Schwille P. Equinatoxin II permeabilizing activity depends on the presence of sphingomyelin and lipid phase coexistence. Biophys J. 2008;95(2):691698. Available from: https://doi.org/10.1529/biophysj.108.129981

60. Ros U, Edwards MA, Epand RF, et al. The sticholysin family of poreforming toxins induces the mixing of lipids in membrane domains.
Biochim Biophys Acta. 2013;1828(11):2757-2762. Available from: https:// doi.org/10.1016/j.bbamem.2013.08.001

61. Koumanov KS, Tessier C, Momchilova AB, Rainteau D, Wolf C, Quinn PJ. Comparative lipid analysis and structure of detergent-resistant membrane raft fractions isolated from human and ruminant erythrocytes. Arch Biochem Biophys. 2005;434(1):150-158. Available from: https:// doi.org/10.1016/j.abb.2004.10.025

62. Nelson GJ. Lipid composition of erythrocytes in various mammalian species. Biochim Biophys Acta. 1967;144(2):221-232. Available from: https://doi.org/10.1016/0005-2760(67)90152-X

63. Cummings BS, Schnellmann RG. Measurement of cell death in mammalian cells. Curr Protoc Pharmacol. 2004;25:12.8.1-12.8.22. Available from: https://doi.org/10.1002/0471141755.ph1208s25

64. Soto C, Bergado G, Blanco R, et al. Sticholysin II-mediated cytotoxicity involves the activation of regulated intracellular responses that anticipates cell death. Biochimie. 2018;148:18-35. Available from: https://doi. org/10.1016/j.biochi.2018.02.006

65. Alvarado-Mesén J, Solano-Campos F, Canet L, et al. Cloning, purification and characterization of nigrelysin, a novel actinoporin from the sea anemone Anthopleura nigrescens. Biochimie. (in press).

66. DiPeso L, Ji DX, Vance RE, Price JV. Cell death and cell lysis are separable events during pyroptosis. Cell Death Discov. 2017;3:17070. Available from: https://doi.org/10.1038/cddiscovery.2017.70

67. Mancheño JM, Martín-Benito J, Martínez-Ripoll M, Gavilanes JG, Hermoso JA. Crystal and electron microscopy structures of sticholysin Il actinoporin reveal insights into the mechanism of membrane pore formation. Structure. 2003;11(11):1319-1328. Available from: https:// doi.org/10.1016/j.str.2003.09.019

68. Moonah S, Sanders NG, Persichetti JK, Sullivan DJ Jr. Erythrocyte lysis and Xenopus laevis oocyte rupture by recombinant Plasmodium falciparum hemolysin III. Eukaryot Cell. 2014;13(10):1337-1345. Available from: https://doi.org/10.1128/EC.00088-14 